\title{
Perancangan Sistem Informasi Alumni STIKOM Dinamika Bangsa Jambi Berbasis Android
}

\author{
Arif Awaludin ${ }^{1}$, Amroni $^{2}$, Hendri $^{3}$ \\ Program Studi Teknik Informatika, STIKOM Dinamika Bangsa, Jambi \\ Jl. Jendral Sudirman Thehok - Jambi Telp. 0741-35095 \\ E-mail:Arifajo08@gmail.com ${ }^{1}$,Amroni@stikom-db.ac.id ${ }^{2}$, Hendri@stikom-db.ac.id ${ }^{3}$
}

\begin{abstract}
Currently the presentation of Information from STIKOM Dinamika Bangsa Jambi Alumnies uses two ways, namely wall magazine (mading) and Online, both in the form of a website, or a Facebook page. From the results of interviews obtained from several STIKOM Dinamika Bangsa Jambi Alumnies, the use of websites is still not effective, the problem is that information is not up to date, and observations show that the website display is not responsive to the appearance of smartphones. To overcome this problem, it is necessary to use the Android-based STIKOM Dinamika Bangsa Jambi Alumnies Information System using the waterfall system development method. System design is made with object-oriented modeling tools, namely Use Case, Activity Diagram, and Class Diagram. This system is expected to help access communication among fellow Alumnies more effectively, be more responsive to Smarthphone and Alumnies can provide or view job vacancy information and advice.
\end{abstract}

Keywords: STIKOM, Information System, Responsive, Alumnies

\begin{abstract}
Abstrak
Saat ini penyajian Informasi alumni STIKOM Dinamika Bangsa Jambi menggunakan dua cara yaitu majalah dinding (mading) dan secara Online, baik berupa website, maupun halaman Facebook. Dari hasil wawancara yang didapat dari beberapa alumni STIKOM Dinamika Bangsa Jambi menyatakan penggunaan website masih kurang efektif, kendalanya ialah informasi yang tidak up to date, dan hasil observasi menunjukkan tampilan website tidak responsive terhadap tampilan smartphone. Untuk mengatasi persoalan tersebut, maka diperlukan Sistem Informasi Alumni STIKOM Dinamika Bangsa Jambi Berbasis Android dengan menggunakan metode pengembangan sistem waterfall. Rancangan sistem dibuat dengan alat bantu pemodelan berorientasi objek yaitu Use Case, Activity Diagram, dan Class Diagram. Sistem ini diharapkan dapat membantu akses komunikasi sesama alumni secara lebih efektif, lebih responsive dengan smarthphone dan alumni dapat memberikan ataupun melihat informasi lowongan pekerjaan dan saran.
\end{abstract}

Kata Kunci: STIKOM, Sistem Informasi, Responsive, Alumni.

() 2019 Jurnal Ilmiah MEDIA SISFO.

\section{Pendahuluan}

Perkembangan teknologi informasi yang semakin pesat pada saat ini menunjukan betapa semakin banyak media informasi yang beredar dalam masyarakat, hal ini mendorong masyarakat untuk dapat terus memanfaatkan informasi tersebut, sesuia dengan fungsinya. Pemanfaatan teknologi informasi tersebut berperan penting kepada kebutuhan manusia pada zaman sekarang, hal inilah yang mendorong munculnya berbagai inovasi baru dalam penyajian informasi untuk memenuhi kebutuhan informasi. Namun tidak hanya sampai disitu hal lain yang menjadi perhatian adalah yang mana bersama berjalannya waktu telefon genggam yang sering digunakan sudah berinovasi menjadi telephone pintar "smartphone". Masyarakat kini beramai-ramai menggunakan berbagai jenis Smartphone khususnya Android. Menurut data statistik yang terjadi di indonesia pengguna Smartphone pada tahun 2013 mencapai 27,4\% dan tahun 2014 naik mencapai 38,3\% kemudian naik lagi pada tahun 2015 mencapai 52,2\% dan ditahun 2016 
meningkat kembali hingga 69,4\% naik lagi ditahun 2017 mencapai 86,6\% hingga ditahun 2018 meningkat pesat menjadi 103\%. Peningkatan terjadi seiring dengan kemampuan, motivasi, keinginan serta kebutuhan masyarakat terhadap kegunaan dari pada media tersebut.[1]

Android merupakan sistem operasi mobile yang tumbuh di tengah sistem operasi lainnya yang berkembang dimasa ini. Sistem operasi ini menawarkan sebuah lingkungan yang berbeda untuk pengembangan. Karena android yang sifatnya open source. Kini banyak masyarakat yang beralih menggunakan smartphone android untuk dijadikan sebagai media untuk mengakses informasi secara mudah dan cepat. Hal tersebut juga terjadi dikalangan mahasiswa. Salah satu alasan mahasiswa menggunakan smartphone android adalah untuk mengakses informasi edukatif, alasannya karena perkembangan sistem informasi akademik pada universitas-universitas seperti Portal Akademik, digital liberary dan perkembangan dunia internet yang kini menyediakan ribuan hingga jutaan link dan Laman web (situs) yang memuat hal-hal yang bersifat pendidikan seperti riset, ejournal, ebook, ensiklopedi, secara digital.[1]

STIKOM Dinamika Bangsa merupakan salah satu sekolah tinggi ilmu komputer yang ada dikota Jambi. Saat ini penyajian Informasi alumni STIKOM Dinamika Bangsa Jambi mengegunakan dua cara yaitu majalah dinding (mading) dan website portal alumni STIKOM. Dari hasil wawancara yang didapat dari beberapa alumni STIKOM Dinamika Bangsa Jambi menyatakan penggunaan website masih kurang efektif, tidak dapat menampilkan informasi berdasarkan kategori serta informasi yang tidak up to date, dan hasil observasi menunjukkan tampilan website tidak responsive terhadap tampilan smartphone. Penelitian ini bertujuan merancang Sistem Informasi Alumni STIKOM Dinamika Bangsa berbasis android dan merupakan sebuah aplikasi penyajian informasi yang memanfaatkan perangkat seperti komputer atau smartphone yang terhubung dengan internet sebagai media penyajian informasi yang up to date.

\section{Tinjauan Pustaka}

\subsection{Landasan Teori}

Desain atau perancangan dalam pembangunan perangkat lunak merupakan upaya untuk mengkontruksi sebuah sistem yang memberikan kepuasan (mungkin informal) akan spesifikasi kebutuhan fungsional, memenuhi target, memenuhikebutuhan secaraimplisit atau eksplisit dari segi performansi maupun penggunaansumber daya, kepuasan batasan pada proses desain dari segi biaya, waktu, dan perangkat. Kualitas perangkat lunak biasanya dinilai dari segi kepuasan pengguna perangkat lunak terhadap perangkat lunak yang digunakan [2].

UML (Unified Modeling Language), adalah sebuah "bahasa" yang telah menjadi standar dalam industri untuk visualisasi, merancang dan mendokumentasikan sistem piranti lunak. UML menawarkan sebuah standar untuk merancang model sebuah sistem. Dengan menggunakan UML kita dapat membuat model untuk semua jenis aplikasi piranti lunak dimana aplikasi tersebut dapat berjalan pada piranti keras, sistem operasi dan jaringan apapun, serta ditulis dalam bahasa pemrograman apapun [3].

Database di firebase adalah database berbasis cloud dan tidak memerlukan query berbasis SQL untuk menyimpan dan mengambil data.[12] Database sangat andal dan supercepat artinya data diupdate dan disinkronkan dalam waktu singkat dan data tetap terjaga bahkan user kehilangan koneksi internet [4]

MySQL adalah sebuah database manajemen system (DBMS) popular yang memiliki fungsi sebagai relational database manajemen system (RDBMS). Selain itu MySQL software merupakan suatu aplikasi yang sifatnya open source serta server basis data MySQL memiliki kinerja sangat cepat, reliable, dan mudah untuk digunakan serta bekerja dengan arsitektur client server atau embedded systems [5].

\subsection{Penelitian Sejenis}

Penelitian dengan judul Perancangan Sistem Informasi Pendataan Alumni Fakultas Ekonomi Universitas Methodist Indonesia Berbasib Web, ditulis oleh Rafles Sebayang, Marlyna Infryanty Hutapea dan Roni Jhonson Simamora. Sistem ini memuat informasi tentang data alumni, data kegiatan alumni, dan forum. Jika alumni ingin mengetahui daftar alumni yang terdaftar, daftar kegiatan alumni, dan forum-forum alumni maka alumni yang langsung melakukannya secara online dengan melakukan registrasi terlebih 
dahulu. Setelah alumni tersebut melakukan registrasi, maka alumni tersebut sudah dapat melakukan akses terhadap informasi dan data tersebut diatas.[6]

Penelitian dengan judul Rancang Bangun Sistem Informasi Pendataan Alumni pada STIE Prabumulih Berbasis Website dengan menggunakan Bootstrap, ditulis oleh Ariansyah, Fajriyah dan Febby Satryadi Prasetyo.aplikasi dirancang dengan menggunakan bahasa pemrograman PHP dan database MySQL. website alumni STIE Prabumulih memberikan kemudahan mendata seluruh alumni dan menyediakan informasi yang akurat.[7]

Penelitian berikutnya, Analisis Pengembangan Situs Crowdfunding Sebagai Media Penghubung Alumni dan Civitas Akademika di Lingkungan Jurusan Pendidikan Teknik Elektronika Universitas Negeri Yogyakarta oleh Abdul Rachman Pambudi. Website crowd funding untuk Jurusan Pendidikan Teknik Elektronika UNY dikembangkan menggunakan framework YII. Proses pengembangan berdasarkan model Waterfall yang terdiri dari empat tahap yaitu, (1) Analisis kebtuhan; (2) Desain; (3) Implementasi; dan (4) Pengujian. Websitedapat menangani proses publikasi artikel proyek, pencarian artikel proyek, proses donasi alumni dan manajemen artikel dan donasi proyek.[8]

Penelitian lainnya, Analisis dan Pengembangan Sistem Informasi Alumni Sekolah Berbasis Web di SMA 2 Wates oleh Azis Amirulbahar. Sistem informasi alumni sekolah berbasis web di SMA 2 Wates dalam pengembangannya menggunakan framework Codeigniter. Proses pengembangan software menggunakan model waterfall yang terdiri dari (1) analisis kebutuhan; (2) desain; (3) implementasi; dan (4) pengujian. Sistem ini memiliki 3 level pengguna yaitu admin sekolah, admin dari alumni, serta alumni dengan fitur sesuai hak akses yang dimiliki.[9].

\section{Metodologi}

Metode pengembangan sistem yang digunakan oleh penulis adalah metode waterfall. Model waterfall menekankan perencanaan di tahap awal, model ini memastikan kekurangan desain sebelum mereka dikembangkan. Selain itu, dokumentasi dan perencanaannya yang intensif membuatnya cocok untuk project yang mengutamakan kontrol kualitas [10]. Berdasarkan model waterfall, maka dapat diuraikan pembahasan masing-masing tahap dalam model tersebut adalah sebagai berikut :

1. Analisis Kebutuhan ( Requirements Definition)

Pada tahap ini dilakukan analisis sistem terhadap sistem yang akan dibuat, dengan cara menentukan kebutuhan fungsional mau pun kebutuhan non fungsional dari sistem yang akan dibangun serta batasan-batasan sistem yang akan dibuat.

2. Desain Sistem ( System and software Design)

Tahap ini merupakan tahapan dimana penulis melakukan perancangan berdasarkan analisis yang dilakukan pada tahap sebelumnya, mulai dari menentukan rancangan basis data, userinterface, input dan output yang akan ditampilkan sehingga dalam sistem yang akan dibuat dapat menarik dan dapat menyampaikan informasi secara efektif. Untuk membuat perancangan dari model sistem dengan menggunakan beberapa alat bantu untuk menggambarkan sistem berjalan ataupun sistem baru yang akan dikembangkan secara logika yaitu dengan menggunakan UML (Unified Modeling Language), seperti : Use Case Diagram, Class Diagram dan Activity Diagram.

3. Implementasi dan Pengujian Unit ( Implementation and unit testing )

Tahap ini merupakan proses yang akan memakan waktu yang cukup lama dan yang paling sulit. Tahap ini dimulai dari pembuatan interface aplikasi, kemudian dilanjutkan dengan pengodingan terhadap aplikasi yang akan dibuat. Pada perancangan aplikasi ini penulis menggunakan aplikasi Android Studio.

4. Pengujian Sistem (Integration and system Testing)

Tahap ini dilakukan proses pengujian terhadap aplikasi informasi alumni STIKOM yang telah dibangun. Dan black box dimana penulis melakukan pengecekan hasil keluaran dari aplikasi dan apabila hasil/output dari aplikasi sesuai dengan hasil yang diharapkan. untuk memastikan apakah semua fungsi sistem dapat bekerja dengan baik dan mencari apakah masih adakah kesalahan pada sistem. Pengujian ini bertujuan untuk menjamin kualitas software .

5. Maintenace / Perawatan (Opration and Maintenace)

Pada tahap ini merupakan tahap pemeliharaan atau perawatan pada pengoprasian sistem. Pada tahap ini dapat dilakukan review terhadap sistem pada jangka waktu tertentu. Tujuannya untuk 
meyakinkan apakah sistem memerlukan perbaikan atau penyempurnaan yang harus dilakukan. Dikarnakan penelitian hanya melakukan penelitian semata, maka tahap pemeliharaan ini tidak diterapkan, melainkan hanya sampai tahap pengajuan sistem.

\section{Pembahasan \\ 4.1 Analisis Permasalahan Sistem}

Proses analisis yang sedang berjalan ini sangat penting sebagai dasar untuk merancang suatu sistem yang baru. Hal ini diperlukan sebagai perbandingan antara sistem yang sedang berjalan dengan sistem yang akan dirancang nantinya.

Berdasarkan hasil pengamatan langsung (observasi) dan wawancara yang telah dilakukan, pada STIKOM Dinamika Bangsa Jambi dalam menyampaikan informasi masih bersifat manual menggunakan madding, untuk web portal alumni dengan alamat: "www.alumni.stikom-db.ac.id", sedangkan untuk halaman facebook dengan alamat: https://www.facebook.com/groups/257233385878/. Penggunaan mading dan web portal alumni masih dapat dikatakan kurang efektif dikarnakan beberapa faktor seperti mahasiswa terkadang tidak tau mana informasi baru dan lama, letak mading yang hanya di STIKOM mengharuskan mahasiswa/alumni harus datang ke kampus untuk mendapatkan informasi. Dan jika dari web, tidak adanya notifikasi pemberitahuan dan informasi yang ditampilkan tidak berdasarkan kategori, sehingga para alumni susah untuk membedakan informasi atau saran yang ada, pada web portal alumni STIKOM Dinamika Bangsa Jambi.

Sedangkan berdasarkan hasil kuesioner yang telah peneliti sebarkan tentang portal alumni stikom menyatakan $100 \%$ mengetahui semua dan $100 \%$ pernah membukanya, sedangkan dalam penggunaanya 43,3\% meyatakan sering $20 \%$ menyatakan sering sekali dan $36,7 \%$ menyatakan jarang, rata-rata mereka yang membuka portal alumni stikom dinamika bangsa jambi 96,7\% menggunakan smartphone dan 3,3\% menggunakan PC dan jika dijalankan pada smartphone berdasarkan hasil kuesioner 96,7\% menyatakan tampilan menjadi tidak responsif 3,3\% menyatakan tidak responsif, sedangkan informasi yang ada 96,7\% tidak update 3,3\% update, tidak adanya pembaharuan/notifikasi jika informasi yang update menjadi kendala kerena $100 \%$ alumni menyatakan iya.

Berdasarkan dari beberapa permasalahan yang terjadi, didapatkan solusi pemecahan masalah yaitu merancang aplikasi informasi alumni berbasis android. Sistem ini merupakan aplikasi yang diharapkan dapat memberikan solusi dari pemasalahan yang terjadi pada alumni untuk mendapatkan informasi dan penyampaian informasi. Solusi dari aplikasi yang akan dirancang yaitu, alumni mendapatkan informasi dengan mudah dan cepat dimana saja, jika ada informasi baru masuk aplikasi akan mengeluarkan notifikasi. Informasi yang dapat ditampilkan informasi lowongan pekerjaan, informasi alumni dan informasi umum lainnya yang di tampilkan perkategori.

\subsection{Analisis Kebutuhan Sistem}

Analisa kebutuhan sistem merupakan kegiatan menemukan atau mengidentifikasi masalah, mengevaluasi, membuat model serta membuat spesifikasi sistem. Berdasarkan permasalahan yang dibahas sebelumnya, pada tahap ini penulis menentukan hal-hal detail terkait dengan aplikasi yang di rancang dengan cara menganalisa kebutuhan-kebutuhan baik fungsional maupun non fungsional.

Diagram Use Case merupakan diagram yang menunjukkan fungsionalitas suatu sistem atau kelas dan bagaimana sistem tersebut berinteraksi dan menjelaskan sistem secara fungsional yang terlihat oleh user 


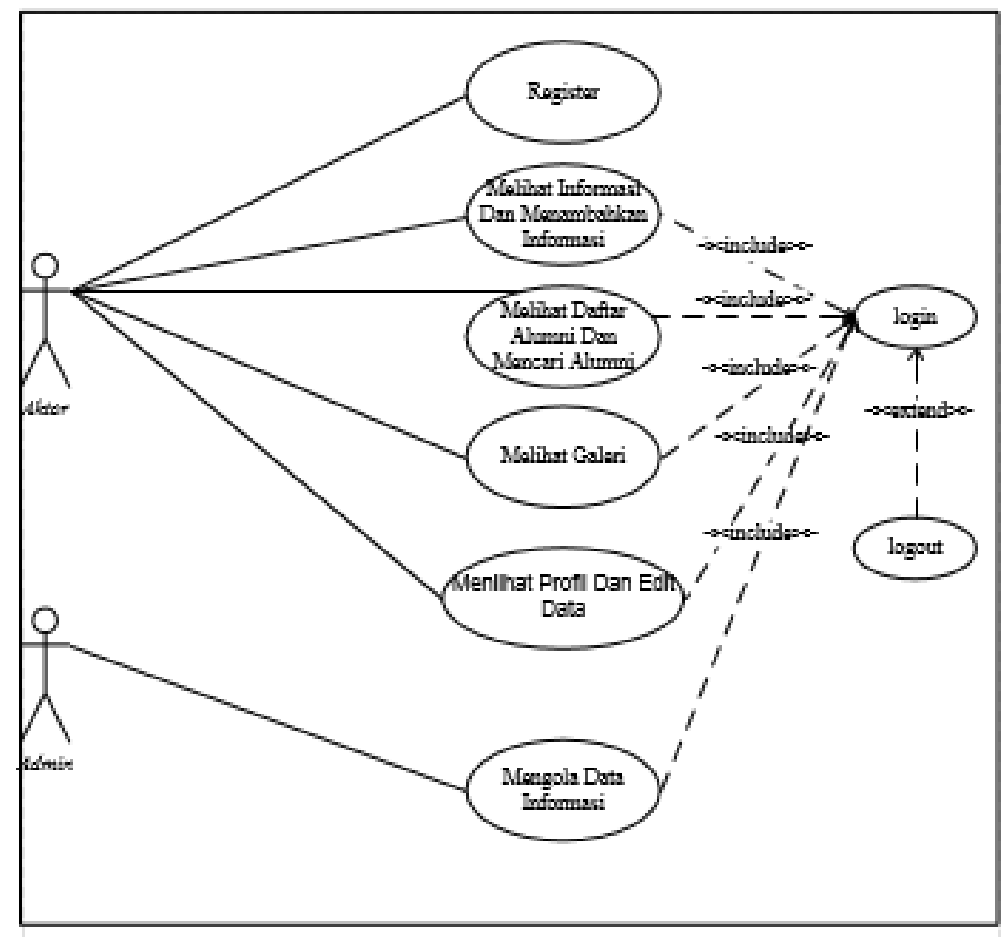

Gambar 1 Use Case Diagram

Dari gambar diatas terlihat bahwa Aktor dapat mendapatkan informasi tentang alumni, seperti informasi lowongan kerja, galeri, dan sebagainya. Sedangkan Admin dapat memanipulasi atau mengelola informasi tentang alumni.

Kebutuhan data untuk perangkat lunak yang akan dibuat dapat di gambarkan dengan class diagram, adapun gambar class diagram yang dibuat adalah sebagai berikut

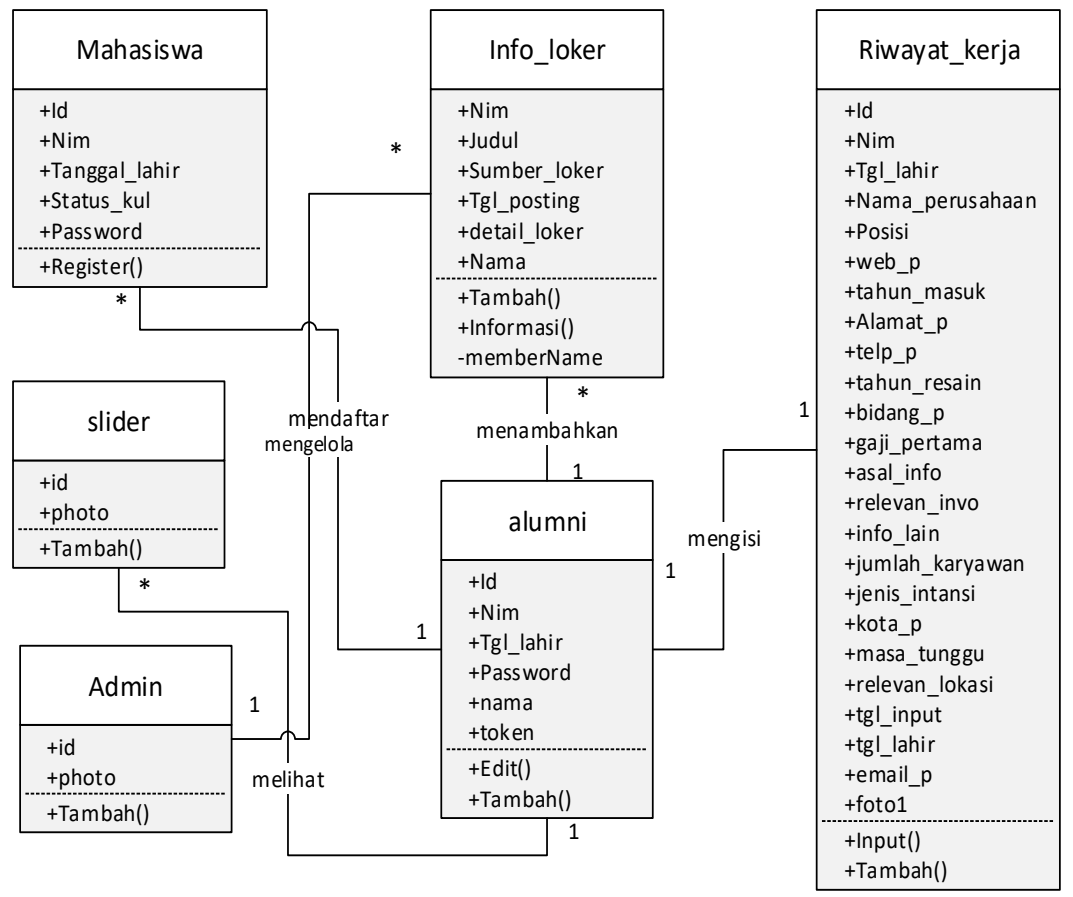

Gambar 2 Class Diagram 


\subsection{Hasil Impelementasi}

Tahapan selanjutnya yang akan dilakukan adalah tahapan implementasi, yaitu proses pembuatan perangkat lunak dari tahap perancangan atau desain ke tahapan coding yang akan menghasilkan perangkat lunak yang telah dirancang sebelumnya. Adapun hasil dari implementasi aplikasi Informasi Alumni STIKOM adalah sebagai berikut :

1. Tampilan Halaman Login

Halaman login merupakan form yang digunakan user untuk masuk kedalam halaman utama Informasi Alumni. Hasil implementasi halaman login dapat dilihat pada gambar 3

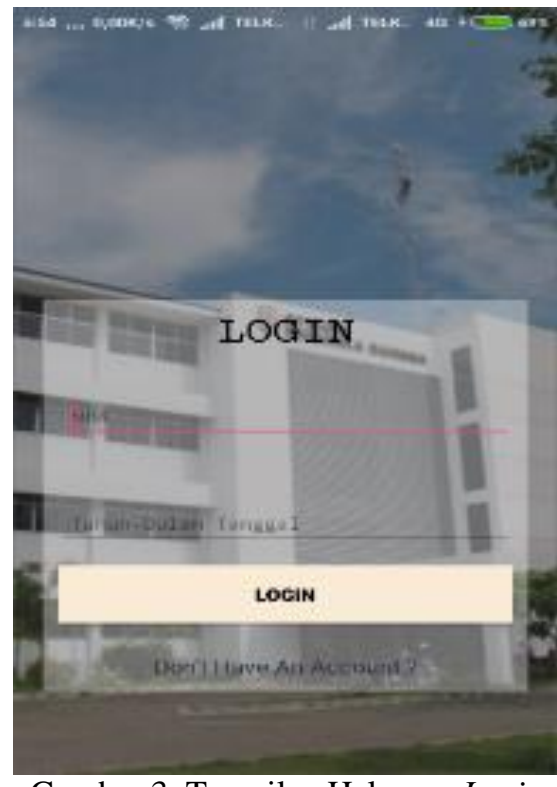

Gambar 3. Tampilan Halaman Login

2. Tampilan Halaman Menu Register

Halaman Register user merupakan form yang digunakan user untuk mendaftar sebuah akun agar dapat login kedalam Informasi Alumni. Hasil implementasi halaman daftar user dapat dilihat pada gambar 4

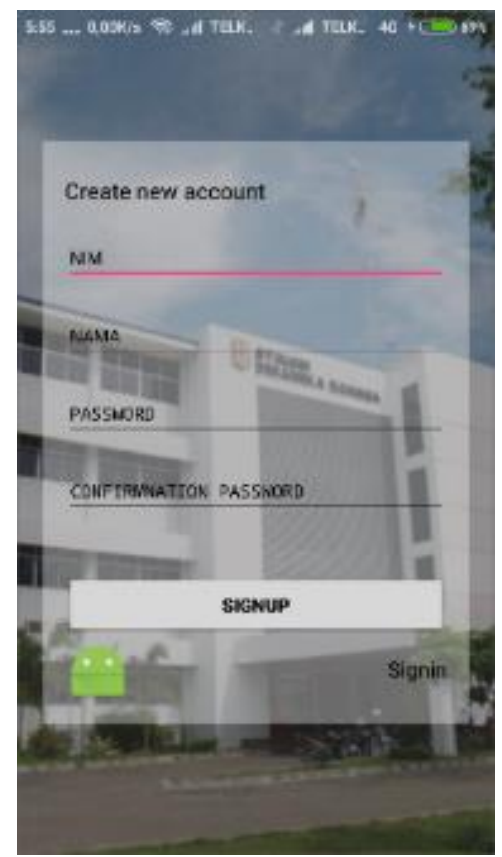

Gambar 4. Tampilan Halaman Menu Register 
3. Tampilan Halaman Menu Utama

Halaman menu utama merupakan halaman awal pada saat user membuka program, dimana user langsung dapat melihat informasi dan pada menu ini terdapat tombol menu navigasi. Hasil implementasi halaman menu utama dapat dilihat pada gambar 5

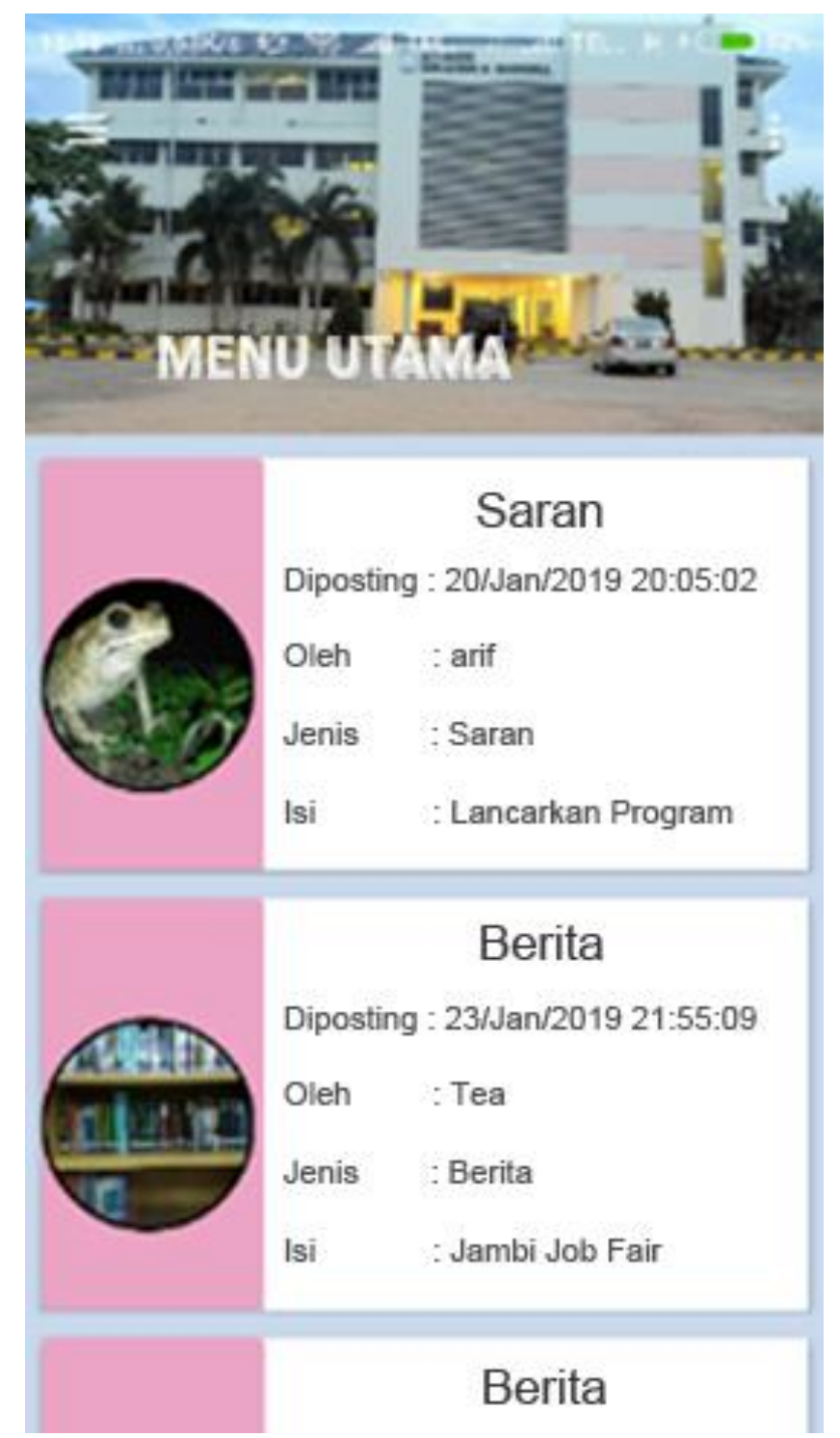

Gambar 5. Tampilan Halaman Menu Utama

4. Tampilan Halaman Menu Drawer

Halaman menu navigasi merupakan halaman dimana user dapat memilih halaman yang akan dituju, terdapat beberapa menu pada navigasi ini. Hasil implementasi menu navigasi dapat dilihat pada gambar 6. 


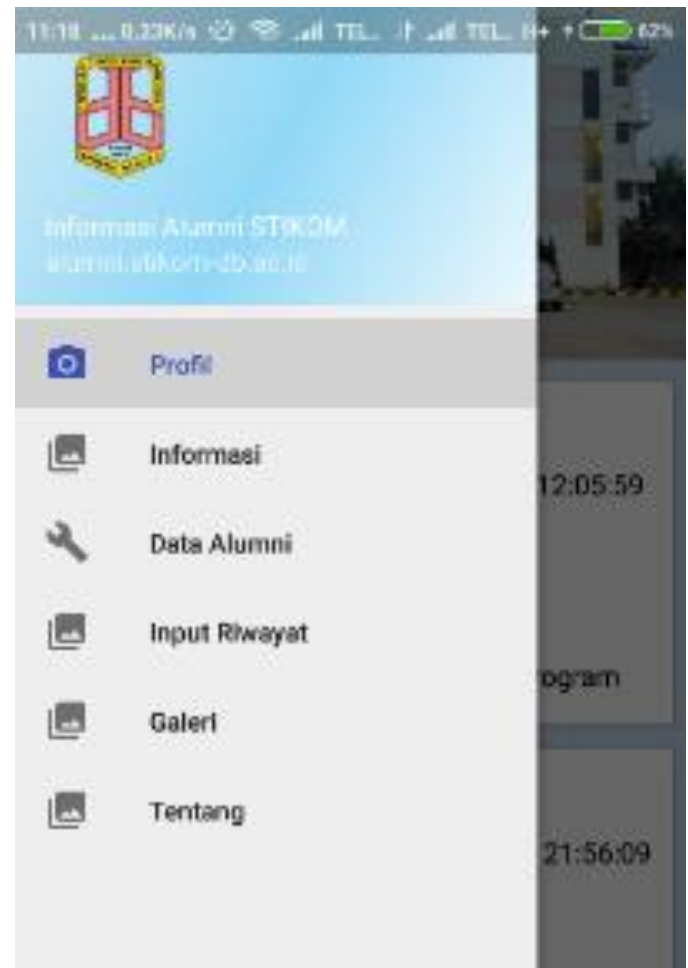

Gambar 6. Tampilan Halaman Menu Drawer

5. Halaman Menu Profil

Halaman Profil merupakan halaman yang menampilkan informasi profil dari user yang menggunakan aplikasi Informasi Alumni STIKOM Dinamika Bangsa Jambi. Hasil implementasi halaman Profil dapat dilihat pada gambar 7 .

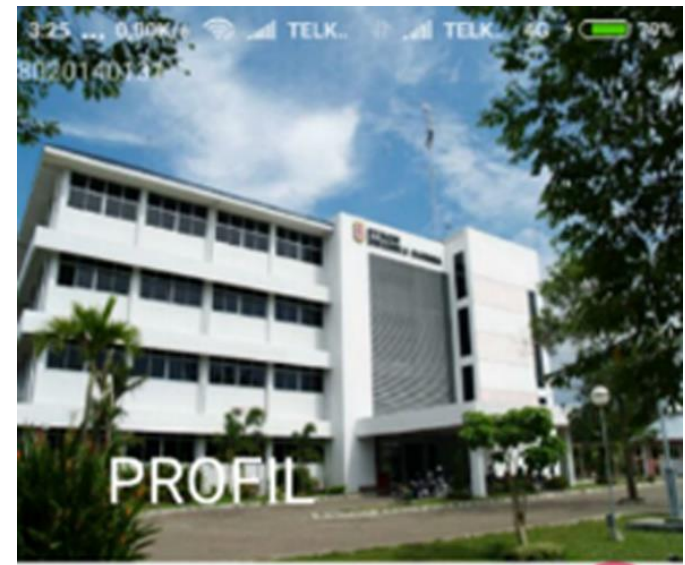

Nama Instansi : PT. Wira Karya Sakti

Posisi : : Staff IT

Tanggal Input : 23 Januari 2019

Gambar 7. Menu Profil 
7. Halaman Lowongan Kerja

Halaman Lowongan Kerja merupakan halaman yang menampilkan informasi lowongan kerja sehingga alumni senantiasa mendapatkan informasi lowongan kerja yang terkini. Hasil implementasi halaman Lowongan Kerja dapat dilihat pada gambar 8.

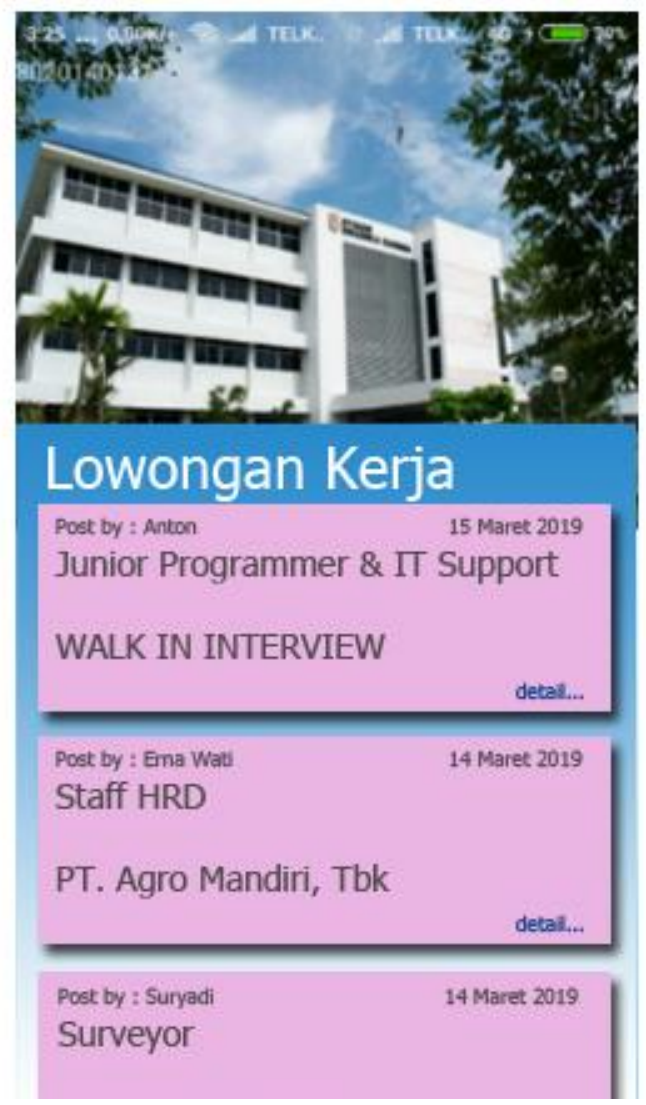

Gambar 8. Halaman Lowongan Kerja

\section{Kesimpulan}

5.1 Simpulan

Setelah tahap dalam penelitian ini dilaksanakan, penulis dapat menyimpulkan hasil dari penelitian ini dilaksanakan sebagai berikut :

1. Aplikasi portal alumni berbasis android dapat diterapkan dalam membantu alumni mendapatkan informasi maupun saran dan mengirimkan informasi atau saran.

2. Sistem ini mempunyai beberapa fasilitas bagi user secara umum dapat mengelompokkan informasi berdasarkan golongannya dan edit data

3. Sistem dapat membei notifikasi jika ada informasi yang up-to-date.

\subsection{Saran}

Penulis menyadari banyak kekurangan dalam aplikasi yang dibuat. Untuk itu dalam kesempatan ini dapat dijabarkan beberapa saran untuk perbaikan aplikasi dimasa yang akan mendatang :

1. Kepada alumni STIKOM Dinamika Bangsa Jambi diharapkan dapat memanfaatkan Sistem Informasi Alumni STIKOM ini.

2. Untuk pengembang/penelitian berikutnya diharapkan dapat menambah fitur-fitur baru yang mungkin masih belum terdapat pada penelitian lain. 


\section{Daftar Rujukan}

[1]. Kominfo, 2018, Jumlah Pengguna Internet 2017 Meningkat, Kominfo Terus Lakukan Percepatan Pembangunan Broadband, https://kominfo.go.id/content/detail/12640/siaran-pers-no53hmkominfo022018-tentang-jumlah-pengguna-internet-2017-meningkat-kominfo-terus-lakukanpercepatan-pembangunan-broadband/0/siaran_pers, akses tanggal 10 Januari 2019

[2]. Rosa AS, M. Shalahuddin. 2011. Rekayasa Perangkat Lunak (Terstruktur dan Berorientasi Objek. Bandung : Modula

[3]. Eddy Prahasta., 2016, Sistem Informasi Geografis : Konsep-Konsep Dasar (Prefektif Geodesi \& Geomatika). Bandung : Informatika Bandung

[4]. Sugiarti, Y. (2013). Analisis dan Perancangan UML (Unified Modeling Language) Generated VB. 6. Yogyakarta: Graha Ilmu..

[5]. Navdeep Singh. 2016. Study of Google Firebase API for Android. ISSN. Vol. 4

[6]. Rafles Sebayang, et. al. Perancangan Sistem Informasi Pendataan Alumni Fakultas Ekonomi Universitas Methodist Indonesia Berbasib Web. METHOMIKA: Jurnal Manajemen Informatika \& Komputerisasi Akuntansi. Vol. 2 No. 1 (April 2018)

[7]. Ariansyah, et. al. .Rancang Bangun Sistem Informasi Pendataan Alumni pada STIE Prabumulih Berbasis Website dengan menggunakan Bootstrap. Jurnal Mantik Penusa Vol. 1 No. 2 Desember 2017

[8]. Abdul Rachman Pambudi. Analisis Pengembangan Situs Crowdfunding sebagai Media Penghubung Alumni Dan Civitas Akademika Di Lingkungan Jurusan Pendidikan Teknik Elektronika Universitas Negeri Yogyakarta (UNY). Skripsi. Universitas Negeri Yogyakarta. 2014

[8] Govardhan, A., 2018, A Comparison Between Five Models Of Software Engineering. IJCSI International Journal of Computer Science Issues 1694-0814. 7. 94-101.

[9] Azis Amirulbahar. Analisis Dan Pengembangansistem Informasi Alumni Sekolah Berbasis Web di SMA 2 Wates. Skripsi. Skripsi. Universitas Negeri Yogyakarta. 2015

[10] Herman Yuliansyah, Perancangan replikasi basis data mysql dengan mekanisme pengamanan menggunakan ssl Encryption. Jurnal Informatika. Vol. 8, No. 1: 827 